\title{
Geophysical study on moraine dam of Imja Glacial Lake in Eastern Nepal using Electrical Resistivity Tomography Method
}

\author{
*Pushpa Raj Dahal ${ }^{1}$, Kabi Raj Paudyal ${ }^{2}$, and Sudhir Rajaure ${ }^{3}$ \\ 1Ministry of Irrigation, Singhdurbar, Kathmandu, Nepal \\ 2Central Department of Geology, Tribhuvan University, Kirtipur, Kathmandu, Nepal \\ 3Department of Mines and Geology, Lainchaur, Kathmandu, Nepal \\ *Corresponding author: pushpardahal@gmail.com
}

\begin{abstract}
Glacial Lake Outburst Flood (GLOF) is one of the potential disaster of Nepal. The Imja glacial lake is considered as one of the fastest growing glacial lake with high risk of GLOF. The internal structure of moraine dams, especially the distribution of buried ice blocks and permafrost materials is key factors in assessing GLOF risk. This study covers exploration and assessment of subsurface conditions of the moraine material such as quantification of buried ice, seepage channel and permafrost material distribution. The geophysical study of dam was carried out by using Dipole-dipole array of Electrical Resistivity Tomography (ERT) method. This study presents the results regarding use of electrical resistivity survey for assessment of the subsurface buried glacier ice and permafrost zones within the dam of the Imja glacial lake. The interpretation of resistivity data at end moraine of Imja glacial lake is based not only on specific resistivity values, but also with field observations and correlation with previous studies. The maximum depth of information obtained from the modeling is about $25 \mathrm{~m}$ and; highest and lowest values of resistivity ranges from $117 \Omega \mathrm{m}$ to $2682240 \Omega \mathrm{m}$. The distribution of major subsurface materials from lowest resistivity value to highest resistivity values are classified as saturated moraine $(<5000$ $\Omega \mathrm{m})$, frozen moraine $(5000 \Omega \mathrm{m}$ to $20000 \Omega \mathrm{m})$ and dead ice $(>20000 \Omega \mathrm{m})$. The distribution of dead buried ice in moraine dam is found to be heterogeneous. The minimum and maximum depth of dead ice from surface is about $0 \mathrm{~m}$ to $20 \mathrm{~m}$ at various locations. Based on the information of this study, an open channel was cut through the lake to lower its level and the result is found to be successful.
\end{abstract}

Keywords: Imja Tsho, ERT, Geophysics, Permafrost, Glacier, Eastern Nepal

Paper Received: 31 Jan 2018

Paper Accepted: 16 March 2018

\section{INTRODUCTION}

The subsidence of the moraine surface is found to be mainly caused by melting of dead ice in the moraine masses, whereas rapid melting of dead ice with formation of cavern along seepage channel may promote topographical instability of the moraine dam. To address mitigation measure of both instability scenario, there is high necessity to obtain information upon the internal structure, distribution and expansion of permafrost materials in the moraine dam, to access the breach potential of the dammed lake.

The Imja glacial lake locally known as the Imja Tsho is situated at the Khumbu Himal, eastern region of the Solukhumbu District of Nepal (Fig. 1). It drains through the Imja River. The lake is formed at the lower tongue of the Imja Glacier at 5010 $\mathrm{m}$ above mean sea level, which is surrounded by several famous peaks Lhotse, Island Peak, Ambulapcha and Lhotsesar and glaciers. The lake is considered as one of the fastest growing lake with high risk of GLOF. It contains tens of millions of cubic meters of water and rapidly expanding the amount of water and depth merely in few decades. Such a drastic amount of water is withheld by lateral and end moraines. It was proposed to lower the lake water level by channeling through a cut made on the outlet or parallel to the outlet avoiding subsurface dead ice. Surface water flowing through the outlet channel with relatively high temperature may trigger melting of subsurface buried ice in contact along the outlet channel, which may lead to catastrophic event by formation of cavern reducing the strength of dam and eventually failure of dam producing GLOF event. A geophysical survey using Electrical Resistivity Tomography (ERT) method was carried out at the end and the lateral moraine masses of the Imja Glacier before selection and construction of a suitable canal alignment to reduce enormous volume of the lake water up to safe level. Study was initiated by CDG in collaboration with GEF, DHM, UNDP into two phases, 2014 October and 2015 April.

The area under investigation lies in the Higher Himalayan crystalline zone with calc. gneiss, migmatite, pegmatite and schists as characteristic rocks and as recent sediments such as scree colluvial deposit below rock exposure. The glacier moraine mass could be found surrounding the glacier and glacial lakes as glacio-fluvial deposits. 


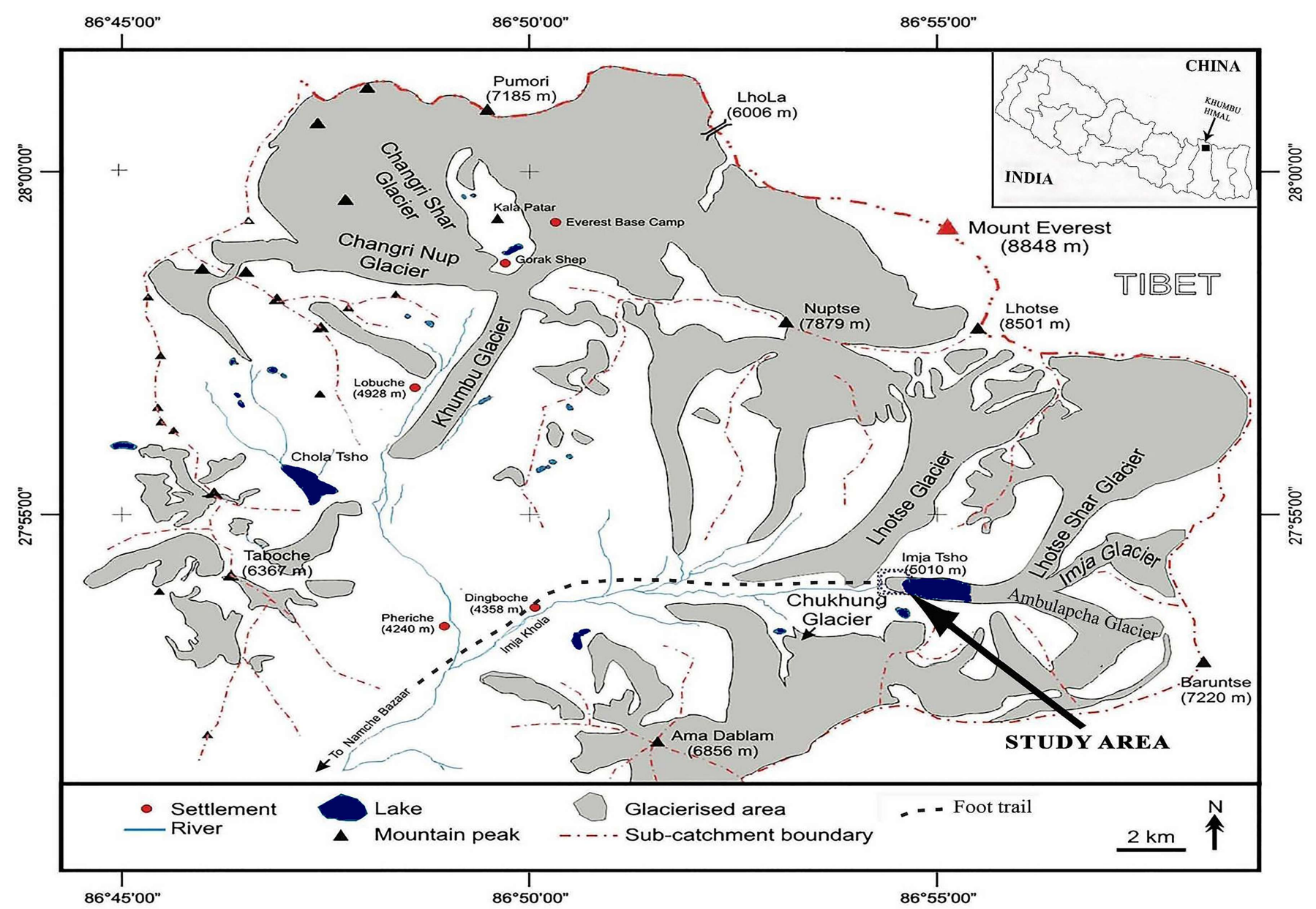

Fig. 1: Location map of Imja glacier area

Study area was previously studied by several scientists. Sakai et al. (2003) and Somos et al. (2014) conducted bathymetric surveys of the Imja Tsho to examine the changes in the depth and noted exponential increase of depth and water volume of lake with time from past decades. McKinney et al. (2013) carried out Ground Penetrating Radar (GPR) survey in several sections, across and parallel to the Imja Lake outlet. They concluded the presence of dead ice and permafrost materials form the surface up to $220 \mathrm{~m}$ beneath the end moraine.

Several geophysical exploration methods have been commonly applied for exploration of the internal structures of moraine dams. According to their physical properties, the electrical method was found to be promising to yield reliable results. In particular, the ERT method has been employed in two previous studies of the glacier dams of eastern Nepal and results of ERT was found to be promising for localization of permafrost materials at dams of Glacial lakes, e.g. Pant and Reynolds (2000) at Thulagi Glacial lake, and Kita (1995) at Tsho Rolpa Glacial lake. On the other hand, resistivity values show high contrast between moraine materials and buried dead ice yielding the highest value of resistivity among permafrost materials. The resistivity of the permafrost materials depends upon not only their original electric character but also the water content and temperature up to some extent. Therefore, comprehensive interpretation of resistivity values is essential for identifying the materials. In this study, we carried out serval two-dimensional (2D) electric profiling at debris-covered glacial moraine mass in Khumbu Himalayas, Eastern Nepal. The interpretation of "distribution patterns" on resistivity profiles is discussed taking consideration of the previous study results.

\section{INSTRUMENTATION AND METHOD OF INVESTIGATION}

An ABEM Terrameter SAS300C was utilised to perform manual ERT survey in the field with booster with inbuilt $12 \mathrm{v}$ DC battery (Fig. 2). Other components of survey included, stainless steel electrodes and insulated wire reels. The equipment is powerful and allows to deeper penetration with use of booster alongside. The minimum input impedance for receiver of instrument is $10 \mathrm{M} \Omega$. The minimum and maximum resistance offered by instrument is 0 and $1.9 \mathrm{M} \Omega$. The topographical survey was carried out by Pentax Total Station. 


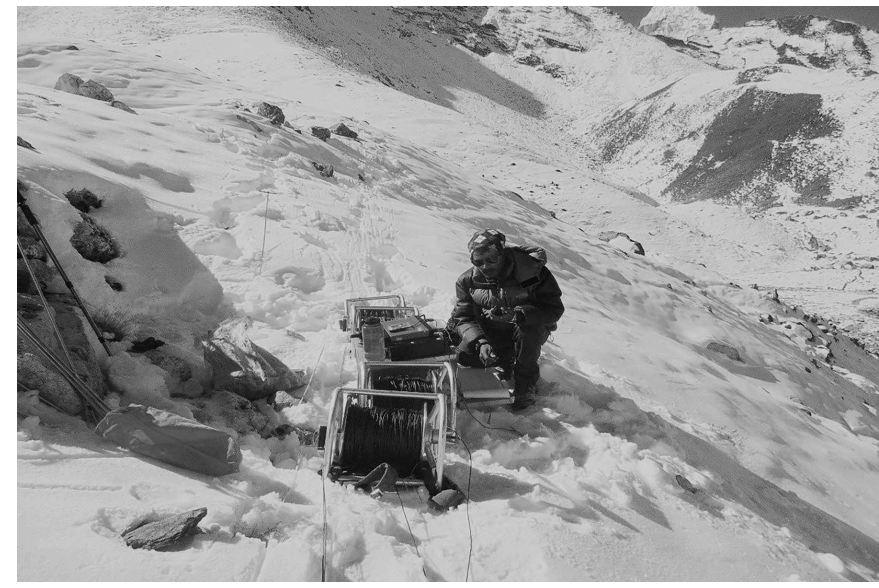

Fig. 2: Instrument (ABEM Terrameter SAS300C) used in survey

Dipole - Dipole array with electrode spacing arrangement as $\mathrm{C}_{1} \mathrm{C}_{2}=\mathrm{P}_{1} \mathrm{P}_{2} ; \mathrm{n} *\left(\mathrm{C}_{1} \mathrm{C}_{2}\right.$ or $\left.\mathrm{P}_{1} \mathrm{P}_{2}\right)=\mathrm{C}_{2} \mathrm{P}_{1}$, is used for electrical profiling due to its low inductive noise and the sensitivity to vertical and horizontal changes in the subsurface resistivity (Loke, 2013), Constant separation of $10 \mathrm{~m}$ between electrodes was maintained for all profiles (i.e. $\mathrm{a}=10 \mathrm{~m}$ ) constant electrode spacing; resistance was measured manually from one to six layers i.e. $\left(\mathrm{C}_{2} \mathrm{P}_{1} / \mathrm{C}_{1} \mathrm{C}_{2}\right)$ or $\left.\left(\mathrm{C}_{2} \mathrm{P}_{1} / \mathrm{P}_{1} \mathrm{P}_{2}\right)=1,2,3, \ldots . .6\right)$ (Fig. 3). Total 20 numbers of ERT alignments were surveyed in first and second phases as shown in Fig. 4 and Fig. 5. The second phase of the study was carried out to densify coverage and data along proposed channels. Distribution of ERT lines was either parallel or across outlet channel of the Imja glacial lake outlet channel.

\section{DATA PROCESSING AND RESULTS}

Measured data along the profiles were inverted by commercially available Res2DINV software (Loke, 2013). Data processing was based on the parameters given in Table 1.
Table 1: ERT Data Inversion Parameters

\begin{tabular}{ll}
\hline $\begin{array}{l}\text { Inversion } \\
\text { Inversion Method }\end{array}$ & $\begin{array}{l}\text { Smoothness constraint non- } \\
\text { linear least square inversion }\end{array}$ \\
$\begin{array}{l}\text { Type of } \\
\text { Optimization }\end{array}$ & Standard Gauss - Newton \\
Forward Model & \\
Model & Model block can exceed number \\
$\begin{array}{l}\text { Discretization } \\
\text { Jacobian matrix } \\
\text { estimation }\end{array}$ & $\begin{array}{l}\text { Quasi-Newton method; } \\
\text { calculated at suitable iteration }\end{array}$ \\
Mesh Parameters & $\begin{array}{l}\text { Finite element method for } \\
\text { topographic modeling }\end{array}$
\end{tabular}

resistivity value, model verification is done with real field condition such as profiles IMJA ERT 7 (Fig. 6) and IMJA T1 (Fig. 7), which show the lowest resistivity values at the top center part, where ERT profiles crosse outlet channel. Similarly, the profiles IMJA ERT1 (Fig. 8) and IMJA ERT10 (Fig. 9) show field observed gneissic boulder extension up to subsurface. Inverted profiles were correlated with work of previous researchers. The correlation used for the analysis of the previous data is given in Table 2 .

Based upon the conducted field measurements, correlation and resistivity model values after inversion, the range of resistivity values were assigned to interpret subsurface permafrost material and water flowing at the outlet channel as shown in Table 3.

The assigned resistivity values are approximate. The resistivity values vary due to heterogeneous distribution of moraine materials. The highest resistance to the flow of current offered by the dead ice yields unambiguity in the recognition in the ERT inverted sections, for example IMJA ERT1 (Fig. 8)

During interpretation of inverted profiles with true
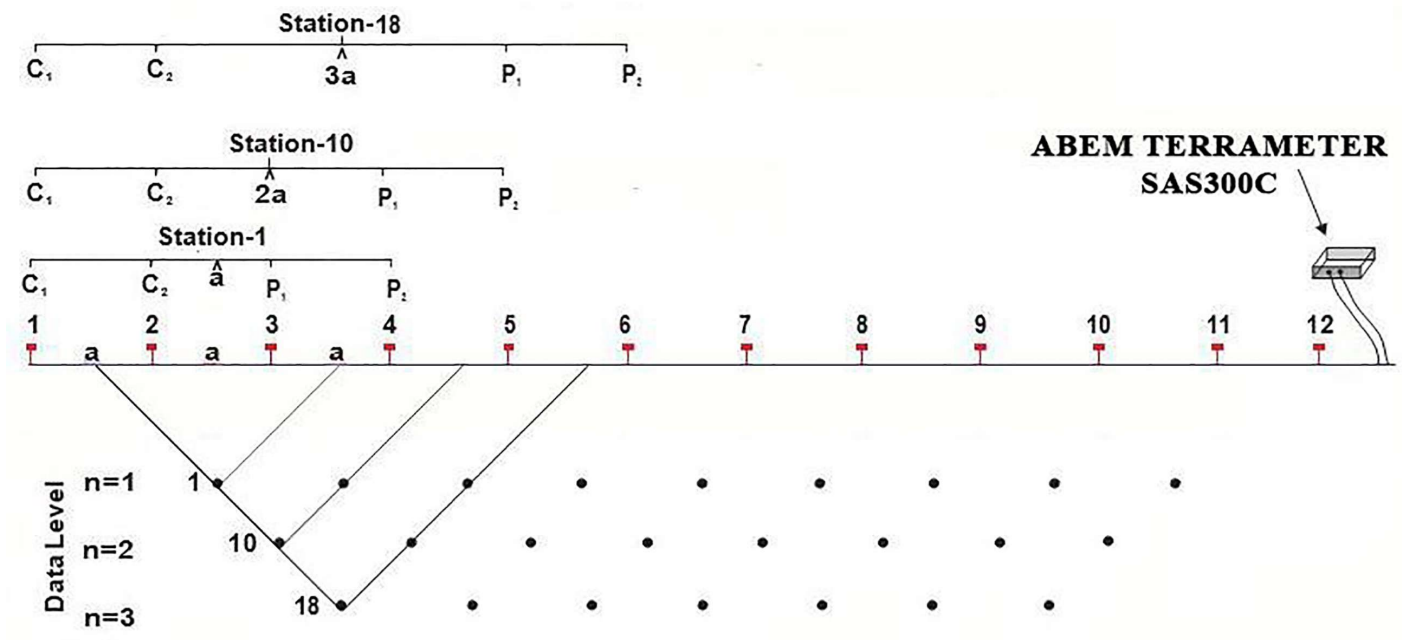

Fig. 3: Measurement of electrical resistivity using dipole-dipole array configuration in the field 


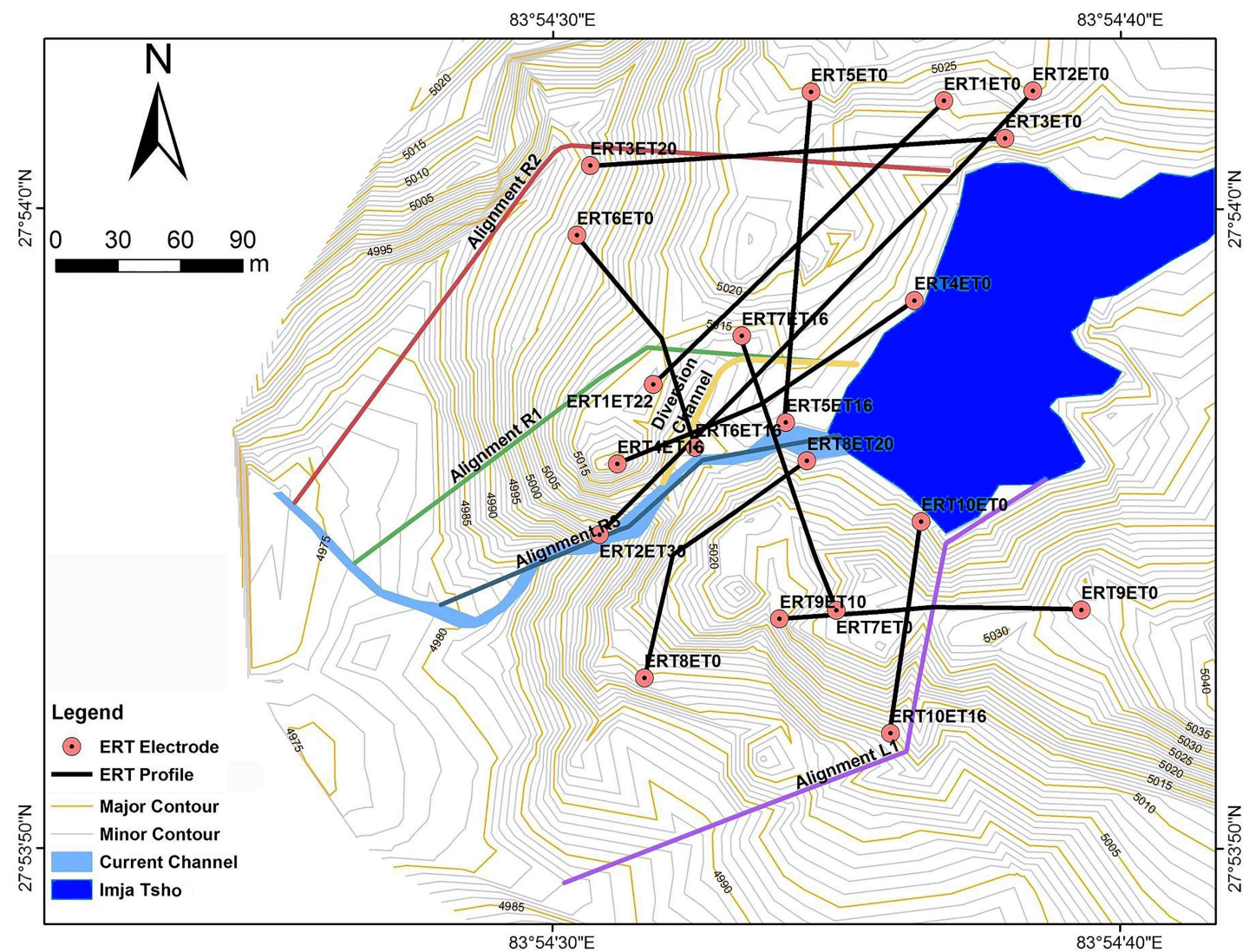

Fig. 4: ERT profiles layout of first phase study in Imja Tsho area

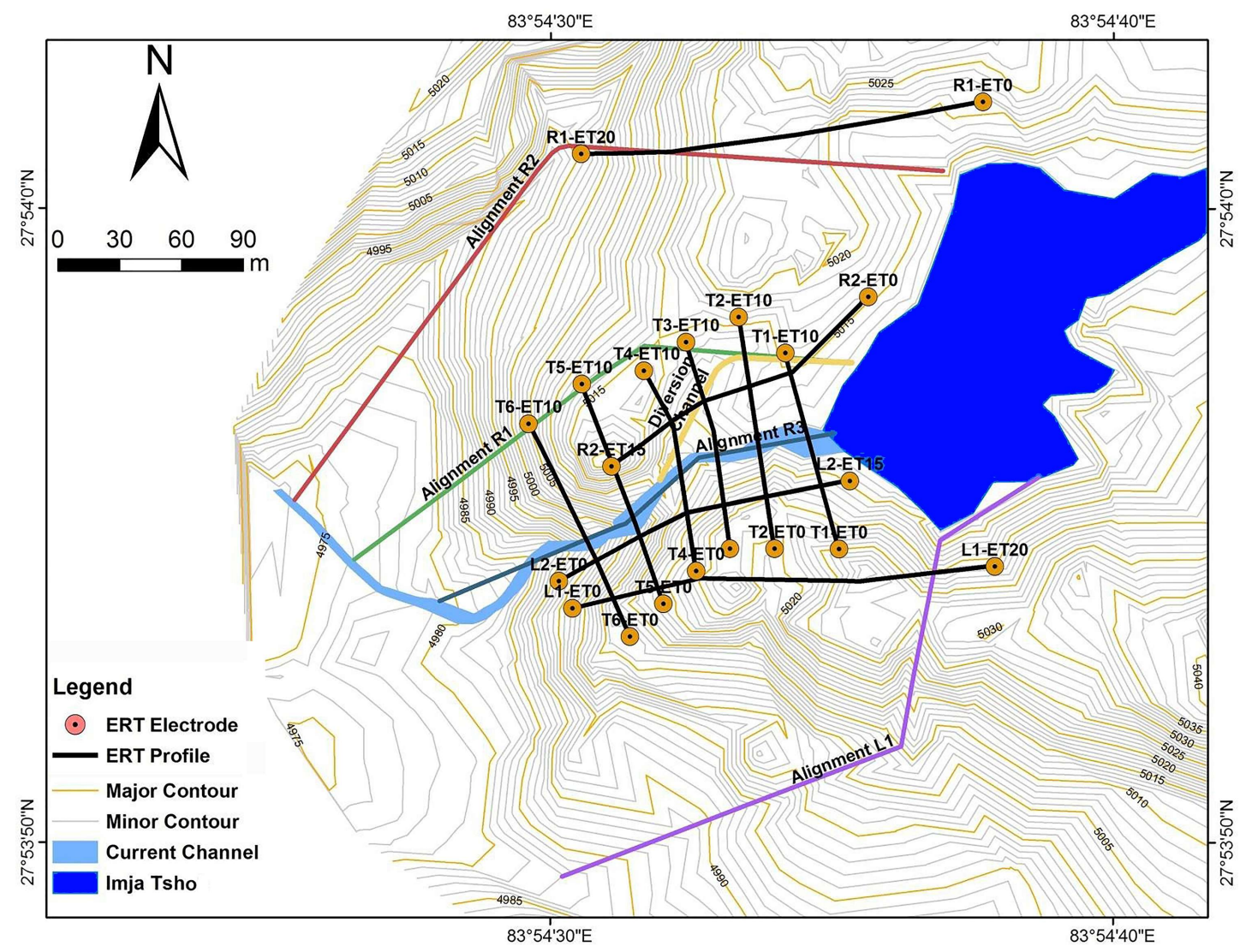

Fig. 5: ERT profiles layout of second phase study in Imja Tsho area 
Fig. 6: (a) Inverse resistivity section along profile IMJA ERT7 and (b) Geological crosssection interpreted from the inversion profile

Fig. 7: (a) Inverse resistivity section along profile IMJA T1 and (b) Geological cross-section interpreted from the inversion profile

Fig. 8: (a) Inverse resistivity section along profile IMJA ERT1 and (b) Ggeological cross-section interpreted from the inversion profile
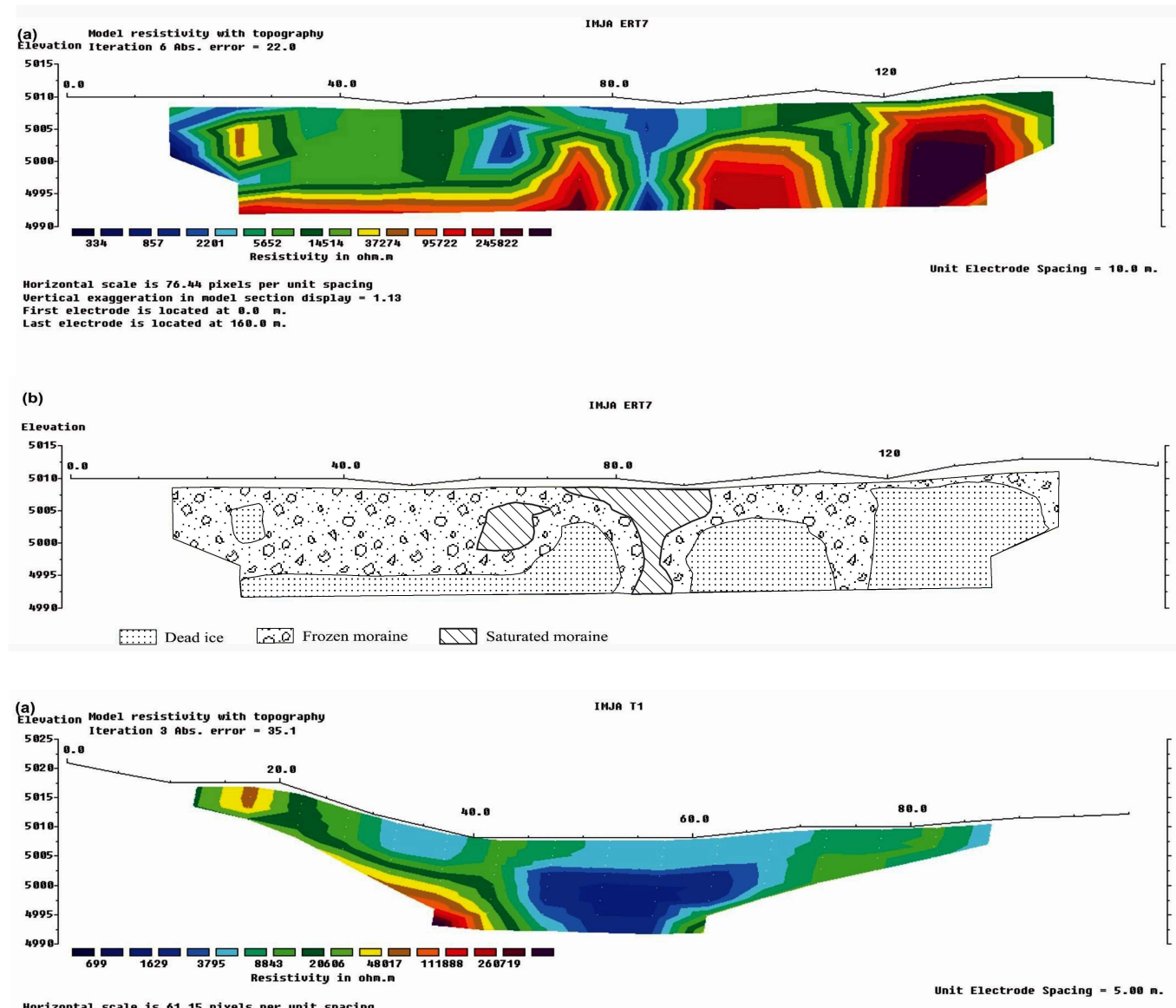

Horizontal scale is 61.15 pixels per unit spacing
Vertical exaggeration in model section display $=0.61$

First electroue is located at $0.0 \mathrm{~m}$.
Last electrode is located at $108.8 \mathrm{~m}$.
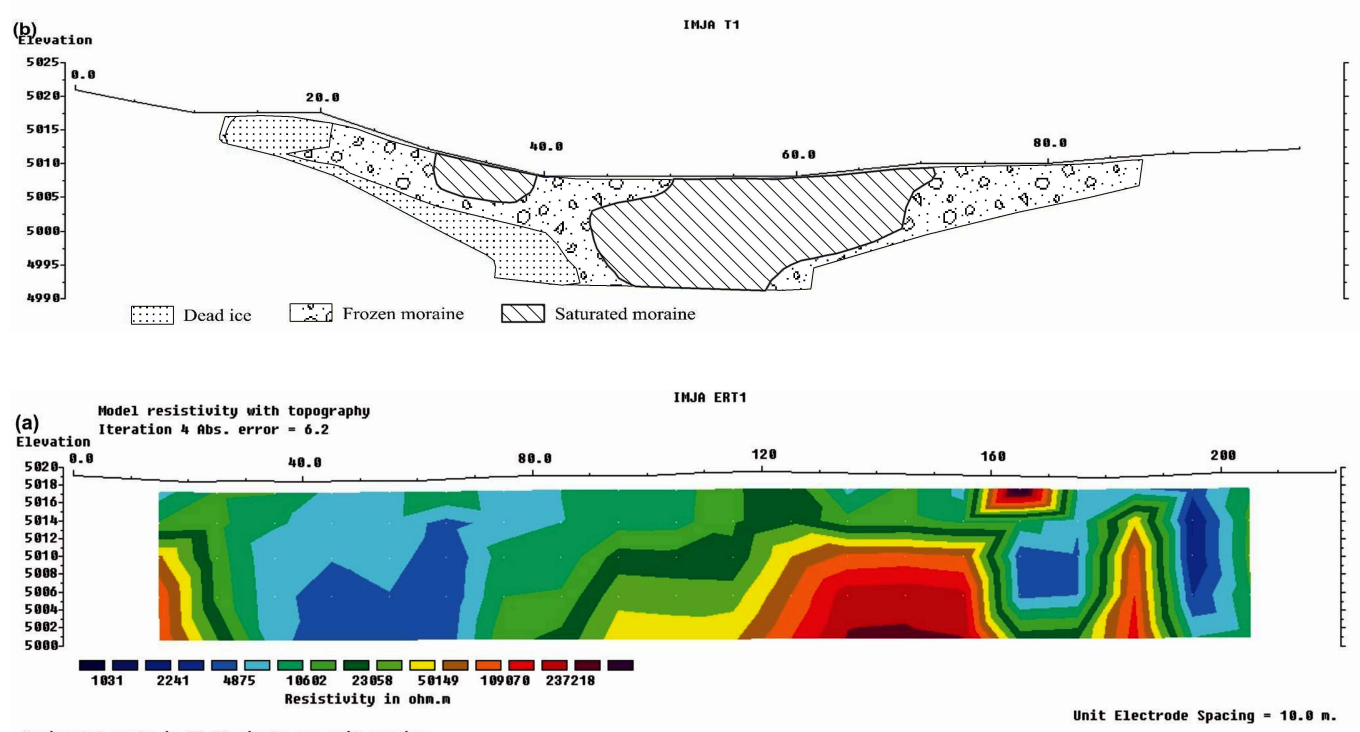
Horizontal scale is 55.59 pixels per unit spacing
Vertical exaggeration in model section display $=1.56$ First electrode is located at $8.8 \mathrm{~m}$.

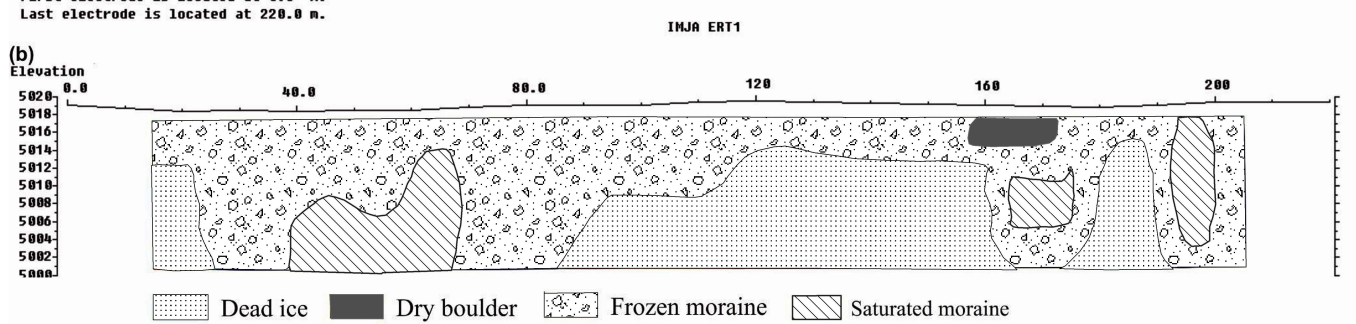




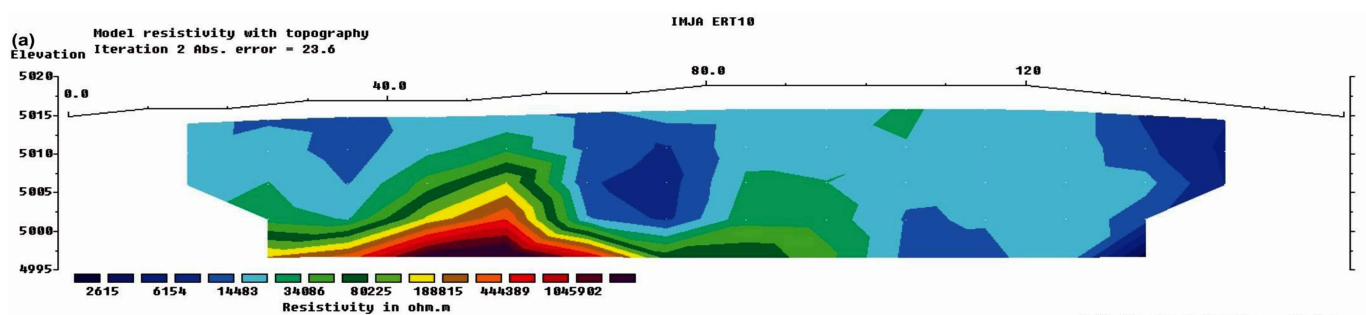

\section{Horizontal scale is 76.44 pixels per unit spacing
Vertical exaggeration in mode1 section display $=1.13$ First electrode is $10 c a t e d$ at $0.8 \mathrm{~m}$.}

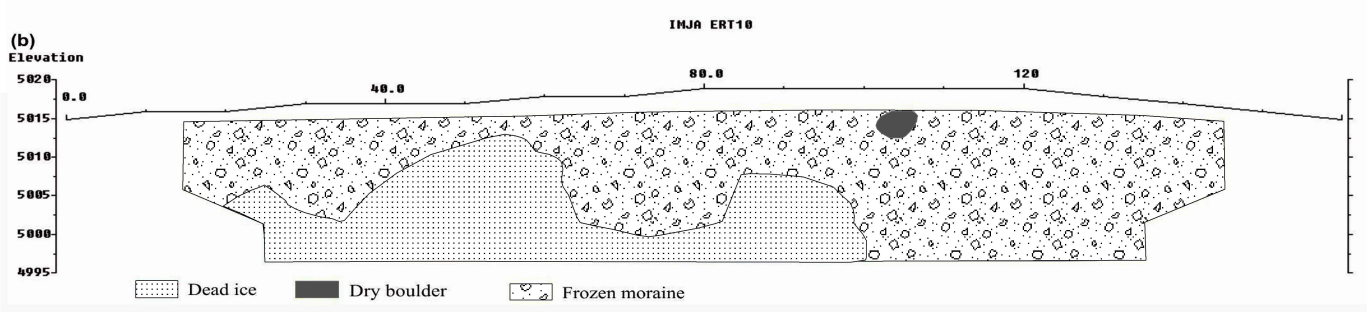

Fig. 9: (a) Inverse resistivity section along profile IMJA ERT10 (b) geological cross-section interpreted from the inversion profile

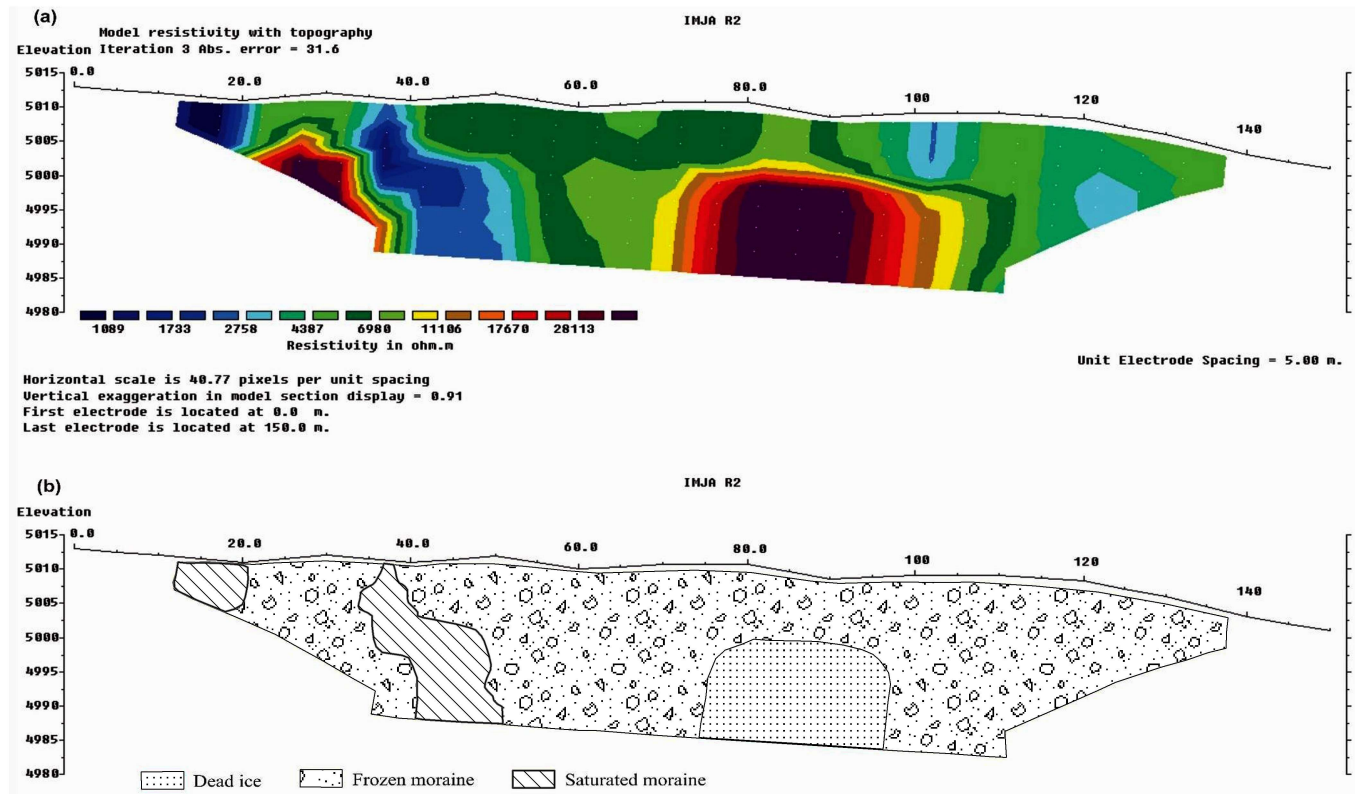

Fig. 10: (a) Inverse resistivity section along profile IMJA R2 and (b) Geological cross-section interpreted from the inversion profile

Table 2: Resistivity value of Permafrost materials

\begin{tabular}{ll}
\hline \multicolumn{1}{c}{ Materials } & Resistivity value \\
\hline Tsho Rolpa Glacier, Kita (1995) & \\
Water saturated debris & $<4 \times 10^{3}$ \\
Unsaturated debris & $>4 \times 10^{3}$ \\
Permafrost & $(5-10) \times 10^{3}$ \\
Dead ice & $>=1 \times 10^{4}$ \\
Thulagi Glacier, Pant and Reynolds (2000) \\
Saturated materials & $<2.5 \times 10^{3}$ \\
Partially saturated materials & $(2-4) \times 10^{3}$ \\
Ice bound permafrost & $(5-30) \times 10^{3}$ \\
Dead ice & $>2 \times 10^{4}$ \\
Lake water & 110
\end{tabular}

Table 3: Assigned Resistivity value for interpretation

\begin{tabular}{ll}
\hline Permafrost Materials & \multicolumn{1}{c}{ Resistivity $(\boldsymbol{\Omega m})$} \\
\hline $\begin{array}{l}\text { Saturated to moist } \\
\text { permafrost materials }\end{array}$ & $<5 \times 10^{3}$ \\
Ice bound permafrost & $(5-20) \times 10^{3}$ \\
Dead ice & $>20 \times 10^{3}$ \\
Lake water & 200 \\
\hline
\end{tabular}

and IMJA R2 (Fig. 10) profiles. Resistivity of lake water is found to be higher than previous studies due to the presence of less soluble geochemical minerals in the lake water.

Among the 20 resistivity surveyed profiles in the study area, only six representative profiles are presented here, though 
cumulative results from all the profiles are used to prepare dead ice distribution map (Fig. 11).

\section{DISCUSSION}

Based on results of ERT profiles and dead ice distribution map, five cross sections were prepared along Alignment R1, R2, R3, L1 and diversion channel (Fig. 11). Such alignments were analyzed for their suitability to make canal and draw water level up to some extent below lake level 5010 m. Evaluation of alignment suitability is based upon the absence or presence of dead ice on those sections to be cut from the surface as shown in Fig. 12. Analytical results of alignments are presented in Table 4.

\section{CONCLUSION}

Geophysical study was carried out by using dipole-dipole array of Electrical Resistivity Tomography (ERT) method around the end moraines of the Imja glacial lake. Interpretation was made based on the standard reference books, published articles and previously published related research reports. Main findings of the present study are summarized in the following points:

a) The depth to buried ice were found in the range of 0 $\mathrm{m}$ to $20 \mathrm{~m}$ underneath the moraine dam at the Imja glacial lake
Table 4: Parameters used for selection of best alignment

\begin{tabular}{cccccc}
\hline $\begin{array}{c}\text { Channel } \\
\text { Alignment }\end{array}$ & R1 & R2 & R3 & L1 & $\begin{array}{c}\text { Diversion } \\
\text { canal }\end{array}$ \\
\hline $\begin{array}{c}\text { Presence of } \\
\text { dead ice }\end{array}$ & Yes & Yes & Yes & Yes & Yes \\
$\begin{array}{c}\text { Depth of dead } \\
\text { ice from lake } \\
\text { level (5010 m) } \\
\text { Length of } \\
\text { alignment (m) } \\
\text { Favorability }\end{array}$ & $\begin{array}{c}3 \mathrm{~m} \\
\text { below }\end{array}$ & $\begin{array}{c}5 \mathrm{~m} \\
\text { above }\end{array}$ & $\begin{array}{c}9 \mathrm{~m} \\
\text { below }\end{array}$ & $\begin{array}{c}12 \mathrm{~m} \\
\text { above }\end{array}$ & 3 m below \\
\hline
\end{tabular}

area. Those buried ice masses were detected on the basis of resistivity values greater than $20,000 \Omega \mathrm{m}$. Similarly, frozen moraine is inferred on the basis of resistivity values from 5,000 $\Omega \mathrm{m}$ to $20,000 \Omega \mathrm{m}$. The resistivity value lower than 5,000 $\Omega \mathrm{m}$ is inferred as saturated moraine.

b) Dead ice distribution map shows that the distribution is heterogeneous in terms of number and depth from the surface. The depth to dead ice is minimum at the left bank of the Imja Tsho outlet as compared to the right bank and the location of dead ice at lowest depth (about $0 \mathrm{~m}$ ) from surface are concentrated in higher number at left bank whereas there is only one location in right bank with the lowest depth (about $0 \mathrm{~m}$ ) of dead ice.

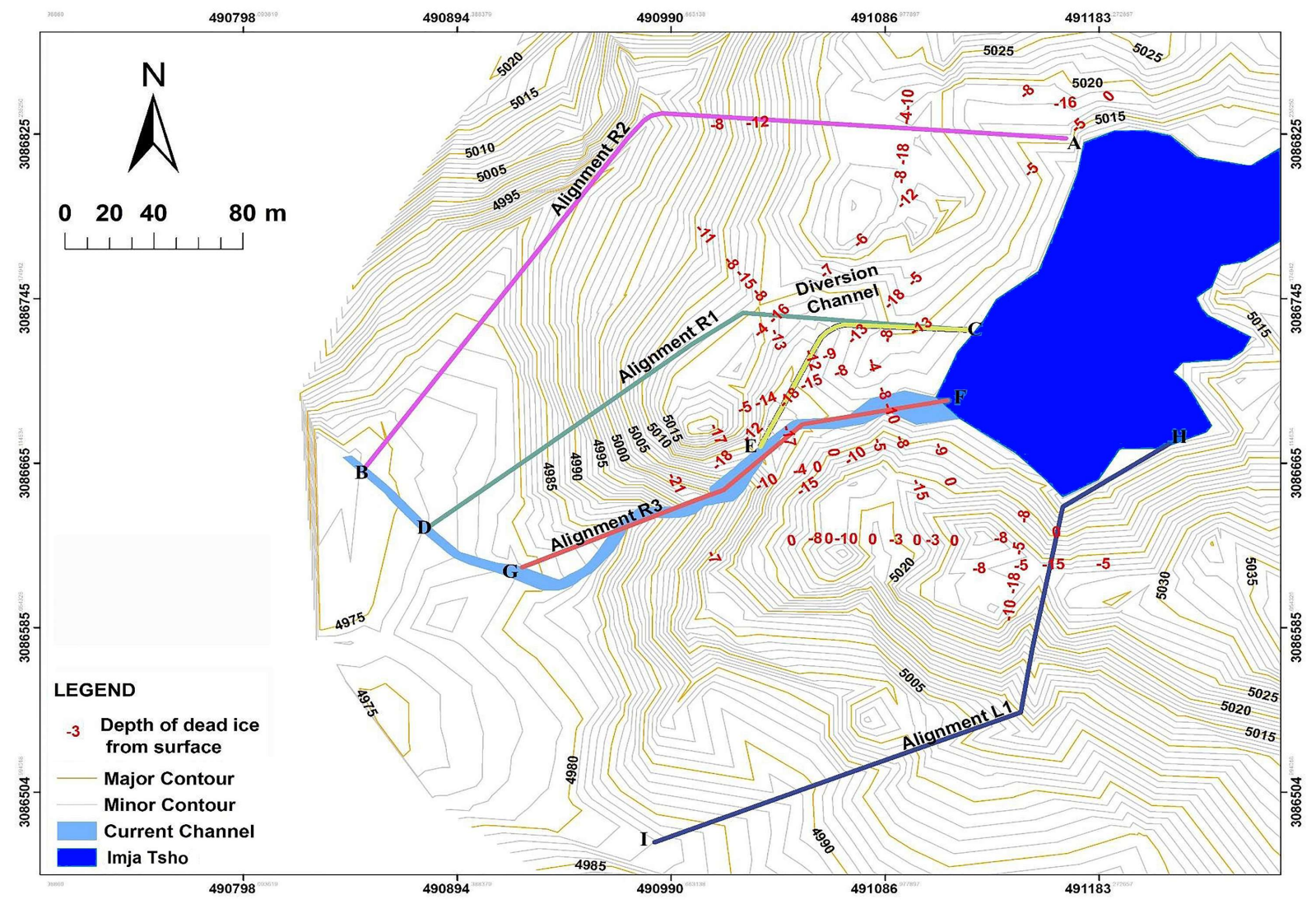

Fig. 11: Map showing distribution of dead ice surrounding Imja Tsho outlet channel 


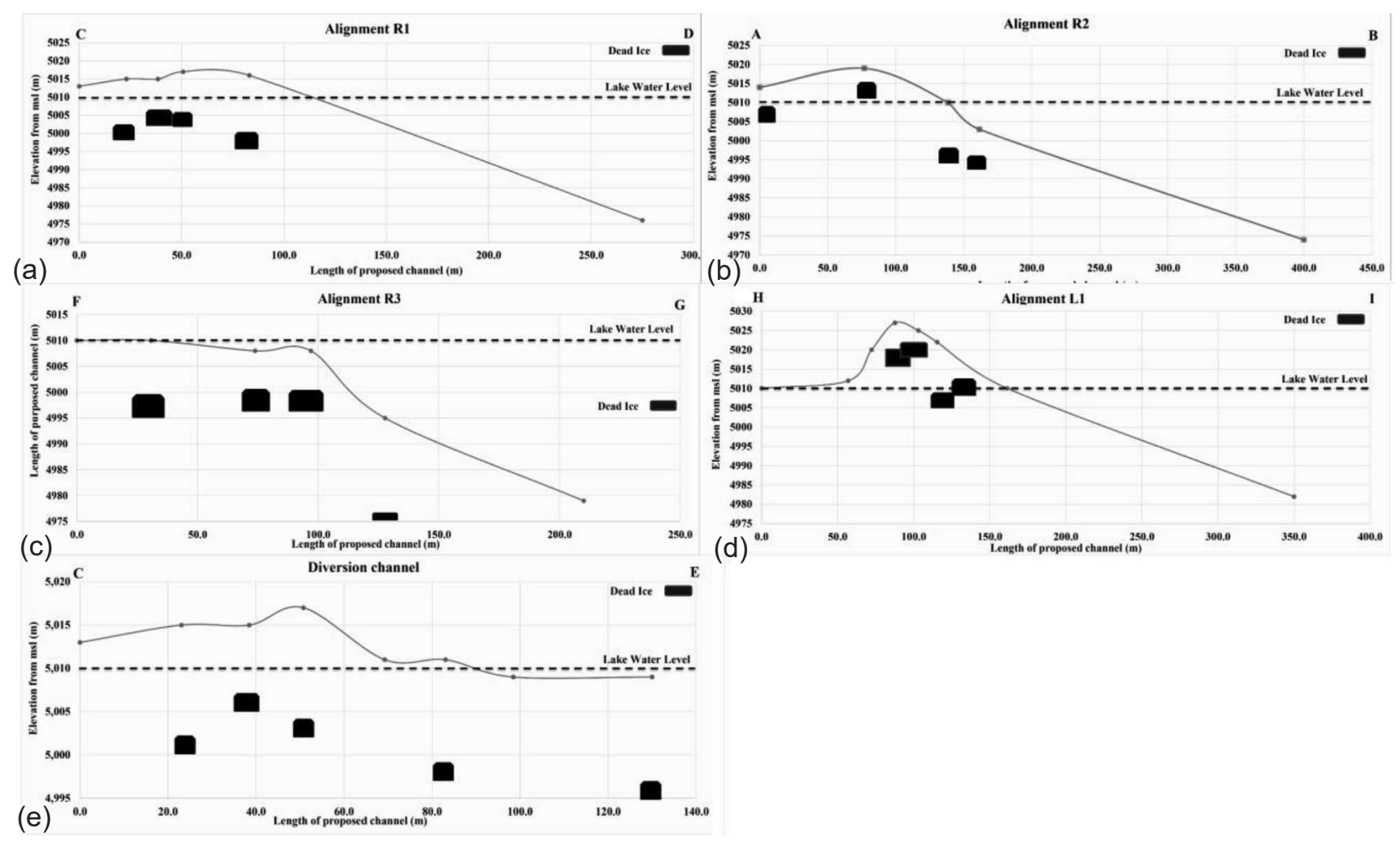

Fig. 12: Cross - section along alignments: (a) CD:R1, (b) AB:R2, (c) FG:R3, (d) HI:L1, and (e) CE:Diversion channel

c) Two possible open channels (Alignments R1 and R3) are proposed for lowering the water of the Imja Tsho up to a safe level based on the distribution of buried ice blocks.

d) Alignment R3 is the best for such purpose (Saturated moraine and frozen moraine) whereas alignment R1 and the diversion channel are suitable for their respective purposes. The final choice depends upon the other parameters such as physical and engineering parameters of the moraine materials.

e) In 2016, Nepal Army reduced the Imja glacial lake up to $3.5 \mathrm{~m}$ below water channel along the alignment R1.

\section{ACKNOWLEDGEMENTS}

Authors thank Mr. Prakash Pokhrel and Mr. Keshav Jaisi for field assistance during data acquisition. Authors are grateful to Mr. Nabaraj Shrestha, 3D Consultants Pvt. Ltd., for valuable suggestions and guidance during interpretation, and Mr. Pravin Raj Maskey, Department of Hydrology and Meteorology, without whose consent, it wouldn't have possible to make this study worthy. Authors are thankful to Central Department of Geology for granting opportunity to carry out study and instrumentation. Authors thank Dr. Alton Byers (University of Colorado), Dr. Deane McKinney (University of Texas), Elizabeth Byers and Daniel Byers for making field trip fruitful.

\section{REFERENCES}

Fujita, K., Sakai, A., Nuimura, T., Yamaguchi, S., and Sharma, R.R., 2009. Recent changes in Imja glacial Lake and its damming moraine in the Nepal Himalaya revealed by insitu surveys and multi-temporal ASTER imagery, Environ. Res. Lett. vol. 4, 45p.

Kita, H., 1995. Electric resistivity exploration Tsho Rolpa end moraine. WECS N551A890YO, 20p.

Loke, M.H., 2013, Tutorial: 2D and 3D Electrical Imaging Surveys. Geotomo Software: Penang, Malaysia. Available from http://www.geoelectrical.com

McKinney D.C., Byers A.C., 2013. Investigation of the Imja Glacial Lake Outburst Flood Risk and Potential Remediation Measures, Khumbu, Nepal: Summary Report. Glacial Flooding and Disaster Risk Management Knowledge Exchange and Field Training, vol. 6. pp. 1-3.

Pant, S.R. and Reynolds, J.M. 2000. Application of electrical imaging techniques for the investigation of natural dams: an example from the Thulagi Glacial lake, Nepal. Journal of the Nepal Geological Society, vol. 22, pp. 211-218.

Somos-Valenzuela, M. A., McKinney, D.C., Rounce, D.R., and Byers, A.C., 2014. Changes in Imja Tsho in the Mount Everest region of Nepal, The Cryosphere, vol. 8, pp. 1661-1671. 